JRNAL ПMПAH

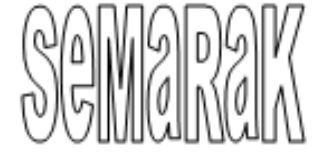

P-ISSN 2615-6849, E-ISSN 2622-3686

Jurnal Semarak,Vol.4,No.1,Februari 2021, Hal (70-79)

@Prodi Manajemen Fakultas Ekonomi Universitas Pamulang

\title{
PENGARUH CURRENT RATIO (CR), RETURN ON ASSETS (ROA) DAN DEBT TO EQUITY RATIO (DER) TERHADAP RETURN SAHAM PERUSAHAAN SUB SEKTOR INDUSTRI KIMIA YANG TERDAFTAR DI BURSA EFEK INDONESIA PERIODE 2014-2018
}

\author{
Reza Octovian dan R. Hendra Winarsa \\ Dosen Universitas Pamulang \\ Email : dosen01431@unpam.ac.id ; dosen01437@unpam.ac.id
}

\begin{abstract}
ABSTRAK
Tujuan penelitian ini adalah untuk mengetahui pengaruh Current Ratio, Debt to Equity, dan Return On Assets terhadap Return saham perusahaan sub sektor industri kimia yang terdaftar di Bursa Efek Indonesia periode 2014-2018 sebanyak 6 sampel.

Penelitian ini menggunakan data kuantitatif, metode yang digunakan dalam penelitian ini mengunakan analisis dekripsi data statistik dan menggunakan uji asumsi klasik dan menggunakan analisis regresi linier berganda, uji kelayakan model yaitu dengan uji-t, uji-f serta koefiesien determinasi. Dalam menganalisis data penelitian ini menggunakan alat bantu program Statistical Product Service and Solutions (SPSS) versi 25 .

Berdasarkan hasil penelitian secara parsial Current Ratio tidak berpengaruh signifikan terhadap return saham perusahaan sub sektor industri kimia yang terdaftar di Bursa Efek Indonesia. Return On Assets dan Debt to Equity secara parsial berpengaruh secara signifikan terhadap return saham perusahaan sub sektor industri kimia yang terdaftar di Bursa Efek Indonesia. Secara Simultan Current Ratio, Debt to Equity dan Return On Assets berpengaruh signifikan terhadap return saham perusahaan sub sektor indutri kimia yang terdaftar di Bursa Efek Indonesia.
\end{abstract}

\section{Kata Kunci : Current Ratio, Return On Assets, Debt to Equity dan Return Saham}

\section{ABSTRACT}

The purpose of this research is to know the effect of Current Ratio (CR), Debt to Equity (DER), and Return On Assets (ROA) on stock return sub sector chemical industry companies in Indonesia Stock Exchange period of 2014-2018 as many as 6 samples.

This research uses quantitative data and this research uses a descriptive analysis of statistical data and uses the classic assumption test, namely normality test, multicolliniearity test, autocorrelation test, heteroscedasticity test and using multiple linear regression analysis, model feasibility test namely t-test, f-test and coefficient of determination. In analyzing the data this study uses a Statistical Product Service and Solutions (SPSS) Program version 25.

Based on the results of partial, Current Ratio does not have a significant effect on stock return sub sector chemical industry companies in Indonesia StockExchange. Return On Assets and Debt to Equity has significant influence on stock return sub sector chemical industry companies in Indonesia Stock Exchange. Taken together simultaneous Current Ratio, Debt to Equitty and Return On Assets has a significant influence on stock return sub sector chemical industry companies in Indonesia Stock Exchange.

Keywords : Current Ratio, Return On Assets, Debt to Equity and Stock Return 
JRNAL ПMМAH

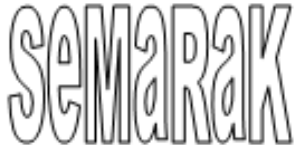

\section{PENDAHULUAN}

\section{A. Latar Belakang}

Perkembangan dunia usaha dewasa ini berkembang pesat, terlebih dengan menghadapi situasi perekonomian yang semakin terbuka. Sejalan dengan itu, maka perusahaan juga semakin terdorong untuk meningkatkan efisiensi dan daya saing kinerja perusahaannya. Perusahaan dalam rangka mengembangkan usahanya membutuhkan tambahan modal yang tidak sedikit. Kebutuhan tambahan modal dapat diperoleh dengan cara pinjaman pihak ketiga atau dengan proses mekanisme right issue

Pemilik perusahaan adalah pihak yang menanamkan dananya di perusahaan (investor). Jika perusahaan yang mengeluarkan saham (emiten) telah go public, maka pemilik perusahaan adalah masyarakat luas yang memiliki saham perusahaan yang bersangkutan. Tujuan memiliki saham suatu perusahaan antara lain adalah ingin memperoleh dividen.

Bursa Efek Indonesia berfungsi untuk menghubungkan para investor, perusahaan-perusahaan dan institusi pemerintah melalui perdagangan intrumen keuangan jangka panjang, dan salah satu intrumen yang diperdagangkan adalah saham. Perkembangan pasar modal di Indonesia mendorong perusahaan untuk menjual sahamnya kepada masyarakat ( $g o$ public).

Dalam kegiatan berinvestasi ini investor mengharapkan sebuah return saham. Return saham merupakan tingkat keuntungan investasi. Para investor mengharapkan return yang maksimal, harapan untuk memperoleh return yang maksimal tersebut diusahakan agar dapat terwujud dengan mengadakan analisis dan tindakan-tindakan yang berkaitan dengan investasi sahamnya. Namun banyak dari investor dan perusahaan belum mengetahui bagaimana cara mengidentifikasi faktorfaktor apa saja yang dapat mempengaruhi sebuah return saham.Investor dalam menanamkan dananya membutuhkan beberapa informasi yang berguna untuk memprediksi hasil investasi dalam pasar modal. Untuk melakukan analisis dan memilih saham terdapat dua pendekatan dasar yaitu, analisis fundamental dan analisis teknikal. Analisis fundamental mencoba memperkirakan harga saham di masa yang akan datang dengan perkiraan nilai faktor-faktor nilai perusahaan yang mempengaruhi harga saham di masa yang akan datang, dan menerapkan hubungan variabel-variabel tersebut sehingga diperoleh taksiran harga saham, Husnan (2009:307). Faktor fundamental dari perusahaan yang dapat menjelaskan kekuatan dan kelemahan kinerja keuangan perusahaan diantaranya dengan menggunakan rasio-rasio keuangan. Melalui rasio-rasio keuangan kita bisa membuat perbandingan.

Saat ini semakin banyak perusahaan yang ikut andil dalam perekonomian pasar bebas di Indonesia. Sama halnya seperti perusahaan sub sektor industri kimia yang ikut berperan dalam permodalan di Bursa Efek Indonesia. Sektor industri dasar dan kimia berhasil mencatat pertumbuhan sebesar $17,08 \%$ year-to-date (ytd). Hal tersebut menjadikan sektor ini sebagai sektor yang pertumbuhannya paling tinggi kedua setelah sektor keuangan yang mencatatkan pertumbuhan hingga 29,18 ytd. nilai Current Ratio terendah dimiliki oleh TPIA sebesar 110,29\% pada tahun 2015, hal ini disebabkan karena pembelian mesin dan penambahan kontruksi yang sedang berjalan terkait ekspansi pabrik Cracker.laporan keuangan perusahaan sub sektor industri kimia yang terdaftar di Bursa Efek Indonesia periode 2014-2018 cenderung fluktuatif. Nilai Return On Assets tertinggi dimiliki oleh TPIA sebesar $14,10 \%$ pada tahun 2016, hal ini disebabkan karena kenaikan volume penjualan pasca ekspansi Cracker dan perseroan diuntungkan dengan harga minyak mentah yang rendah sedangkan nilai Return On Assets terendah dimiliki oleh UNIC sebesar $-0,39 \%$ pada 
JRNAL ПMМAH

Sammadid

tahun 2015, hal ini disebakan karena perseroan menghadapi tantangan yang sangat berat di tengah perlambatan ekonomi global, melimpahnya produk, melimpahnya produk subtitusi, persaingan produk impor, volabilitas dan penurunan harga minyak mentah dunia dan faktor-faktor lain di luar kendali perseroan.

laporan keuangan perusahaan sub sektor industri kimia yang terdaftar di Bursa Efek Indonesia periode 2014- 2018 cenderung fluktuatif. Nilai Debt to Equity tertinggi dimiliki oleh TPIA sebesar 1,22 pada tahun 2014, hal ini disebabkan oleh pencairan hutang dari bank untuk proyek ekspansi Cracker dan nilai Debt to Equity terendah dimiliki oleh INCI sebesar 0,08 pada tahun 2014, hal ini disebabkan oleh kondisi keuangan dan cash flow perseroan sangat terkendali untuk membayar kewajiban hutang usaha

Nilai Return Saham tertinggi dimiliki oleh TPIA sebesar 4,99 pada tahun 2016, hal ini disebabkan oleh peningkatan laba bersih $40 \%$ akibat peningkatan penjualan dan rendahnya harga minyak mentah dan nilai Return Saham terendah dimiliki oleh TPIA sebesar -0,71 pada tahun 2017, hal ini disebabkan karena penurunan laba bersih akibat penjualan yang menurun.

\section{B. Identifikasi Masalah}

1. Investor mengalami kesulitan dalam mengidentifikasi dan menganalisa faktor-faktor yang mempengaruhi return saham.

2. Perusahaan tidak mudah dalam menentukan faktor-faktor yang dapat mempengaruhi return saham.

3. Investor mengalami kesulitan dalam mempertimbangkan faktorfaktor fundamental dalam pengambilan keputusan investasi.

\section{Rumusan Masalah}

1. Bagaimana pengaruh Current Ratio secara parsial terhadap return saham 6 (enam) perusahaan sub sektor industri kimia yang terdaftar di Bursa Efek Indonesia periode 2014-2018.
2. Bagaimana pengaruh Return On Assets secara parsial terhadap return saham 6 (enam) perusahaan sub sektor industri kimia yang terdaftar di Bursa Efek Indonesia periode 2014-2018.

3. Bagaimana pengaruh Debt to Equity Ratio secara parsial terhadap return saham 6 (enam) perusahaan sub sektor industri kimia yang terdaftar di Bursa Efek Indonesia periode 2014-2018.

4. Bagaimana pengaruh Current Ratio, Return On Assets dan Debt to Equity secara simultan terhadap return saham 6 (enam) perusahaan sub sektor industri kimia yang terdaftar di Bursa Efek Indonesia periode 2014-2018.

\section{TINJAUAN PUSTAKA}

\section{A. Return Saham}

Menurut Hartono (2014:263) return adalah apa yang kita peroleh dari investasi. Return dapat berupa return realisasi (Realized Return). Atau return ekspektasian (Expected Return), return realisasi merupakan return yang telah terjadi yang dihitung berdasarkan data historis. Return realisasi sangat signifikan sebagai barometer penentu kinerja perusahaan. Return ekspetasian adalah return yang diharapkan akan diinginkan investor dimasa mendatang, jadi return ekspektasian sifatnya belum terjadi.

$$
\mathrm{Ri}=\text { Return Saham }=\frac{p t-(P t-i)}{(P t-i)}
$$

\section{B. Rasio Keuangan}

Mardiyanto (2009:51) mengatakan analisis rasio keuangan membutuhkan pemahaman yang mendalam tentang berbagai aspek keuangan berikut keterkaitannya satu sama lain.

1. Current Ratio (CR) 
JRNAL ПMМAH

Samidaldad

Rasio ini digunakan untuk mengetahui seberapa jauh aktiva lancar perusahaan digunakan untuk melunasi hutang lancar (kewajiban jangka pendek) yang akan jatuh tempo atau segera dibayar. Sebagai pedoman umum Current Ratio $200 \%$ sudah dianggap baik, khususnya bagi perusahaan industri. Perhitungan Current Ratio(CR) dirumuskan sebagai berikut, Sugiyono (2009:68):

\section{Current Ratio $\frac{\text { AktivaLancar }}{\text { HutangLanca }} \times 100 \%$}

\section{Return On Assets(ROA)}

Rasio ini mengukur tingkat pen gambilan modal yang diinvestasikan dalam keseluruhan aktiva untuk menghasilkan keuntungan bersih dari sebuah bisnis yang dijalankan oleh perusahaan. Semakin tinggi rasio ini berarti perusahaan semakin mampu mendayagunakan aset dengan baik untuk memperoleh keuntungan, begitupula sebaliknya. Perhitungan Return On Assets (ROA) dirumuskan sebagai berikut, Sugiyono (2009:79):

$$
\text { Return On Asset }=\frac{\text { LabaBersih }}{\text { TotalAktiv }} \times 100 \%
$$

\section{Debt to Equity Ratio (DER)}

Rasio ini menunjukkan perbandingan utang dan modal. Semakin tinggi rasio ini maka semakin rendah kemampuan modal sendiri dalam menjamin hutang jangka panjangnya, sehingga akan semakin berisiko bagi perusahaan dan begitu pula jika sebaliknya. Perhitungan Debt to Equity Ratio (DER) dirumuskan sebagai berikut, Sugiyono (2009:71):

$$
\text { Debt to Equity Ratio }=\stackrel{\text { Total }}{\text { TotalModal }}
$$

\section{Hipotesis}

1. $\mathrm{H}_{\mathrm{a}}$ : Diduga terdapat pengaruh signifikan Current Ratio secara parsial terhadap return saham.

$\mathrm{H}_{0}$ : Diduga tidak terdapat pengaruh signifikan Current Ratio secara parsial terhadap return saham.

2. $\mathrm{H}_{\mathrm{a}}$ : Diduga terdapat pengaruh signifikan Return On Assets secara parsial terhadap return saham.

$\mathrm{H}_{0}$ : Diduga tidak terdapat pengaruh signifikan Return On Assets secara parsial terhadap return saham.

3. $\mathrm{H}_{\mathrm{a}}$ : Diduga terdapat pengaruh signifikan Debt to Equity secara parsial terhadap return saham. $\mathrm{H}_{0}$ : Diduga tidak terdapat pengaruh signifikan Debt to Equity secara parsial terhadap return saham.

4. $\mathrm{H}_{\mathrm{a}}$ : Diduga terdapat pengaruh signifikan Current Ratio, Return On Assets, dan Debt to Equity secara simultan terhadap return saham. $\mathrm{H}_{0}$ : Diduga tidak terdapat pengaruh signifikan Current Ratio, Return On Assets, dan Debt to Equity secara simultan terhadap return saham.

\section{METODOLOGI PENELITAN}

\section{A. Ruang Lingkup Penelitaan}

\section{Tempat Penelitian}

penelitian yang dilakukan adalah observasi tidak langsung berupa data sekunder dengan menggunakan data yang ada pada 
JRNAL IMMAH

Samidaldad

situs

www.idx.co.iddan

www.sahamok.com,

2. Waktu Peneltian

penulis mendata laporan keuangan dari perusahaan. Penelitian ini dilaksanakan selama 1 tahun 2019-202

\section{B. Populasi dan Sampel}

\section{Populasi}

Populasi penelitian ini adalah 11 perusahaan sub sektor industri kimia yang terdaftar di Bursa Efek Indonesia (BEI). Berikut adalah table perusahaan sub sektor industri kimia yang terdaftar di Bursa Efek Indonesia (BEI)

\section{Daftar Perusahaan Sub Sektor Industri Kimia yang Terdaftar BEI Periode} 2014-2018

\begin{tabular}{|c|l|c|}
\hline No & \multicolumn{1}{|c|}{ Nama Perusahaan } & $\begin{array}{c}\text { Kode } \\
\text { Saham }\end{array}$ \\
\hline 1 & $\begin{array}{l}\text { PT Chandra Asri } \\
\text { Petrochemical Tbk }\end{array}$ & TPIA \\
\hline 2 & $\begin{array}{l}\text { PT Duta Pertiwi } \\
\text { Nusantara Tbk. }\end{array}$ & DPNS \\
\hline 3 & $\begin{array}{l}\text { PT Ekadharma } \\
\text { International Tbk. }\end{array}$ & EKAD \\
\hline 4 & PT Indo Acidatama Tbk. & SRSN \\
\hline 5 & $\begin{array}{l}\text { PT Intanwijaya } \\
\text { Internasional Tbk. }\end{array}$ & INCI \\
\hline 6 & $\begin{array}{l}\text { PT Unggul Indah Cahaya } \\
\text { Tbk. }\end{array}$ & UNIC \\
\hline 7 & $\begin{array}{l}\text { PT Aneka Gas Industri } \\
\text { Tbk }\end{array}$ & AGII \\
\hline 8 & PT Barito Pasific Tbk & BRPT \\
\hline 9 & $\begin{array}{l}\text { PT Budi Starch \& } \\
\text { Sweetener Tbk }\end{array}$ & BUDI \\
\hline 10 & $\begin{array}{l}\text { PT Eterindo Wahanatama } \\
\text { Tbk }\end{array}$ & ETWA \\
\hline 11 & PT Emdeki Utama Tbk & MDKI \\
\hline
\end{tabular}

\section{Sampel}

$$
\text { Pengambilan }
$$

sampel dilakukan dengan menggunakan metode purposive sampling. Dalam pengambilan sampel dilakuakan dengan motede purposive sampling dengan kriteria berikut :

1. Perusahaan sub sektor industri kimia yang terdaftar di Bursa Efek Indonesia selama periode tahun2014-2018.

2. Perusahaan yang mempublikasi laporan keuangan selama periode tahun 2014-2018.

3. Perusahaan yang menerbitkan laporan keuangan per tanggal 31 Desember selama periode pengamatan yaitu tahun 20142018.

\section{Metode Analisis Data}

1. Analisis Rasio

2. Uji Asumsi Klasik ( Uji Linearitas)
a. Uji Normalitas
b. Uji Multikolineritas
c. Uji Heteroskedastisitas

3. Uji Regresi Linier Sederhana

4. Uji Regresi Linier Berganda

5. Koefisien Korelasi

6. Koefisien Determinasi

7. Uji Hipotesis
a. Uji Slimutan(Uji F)
b. Uji Parsial (Uji T)

\section{HASIL PENELITIAN DAN PEMBAHASAN}

\section{A. Uji Asumsi Klasik}

1. Uji Normalitas

One-Sample Kolmogorov-Smirnov Test Unstandardized Residual

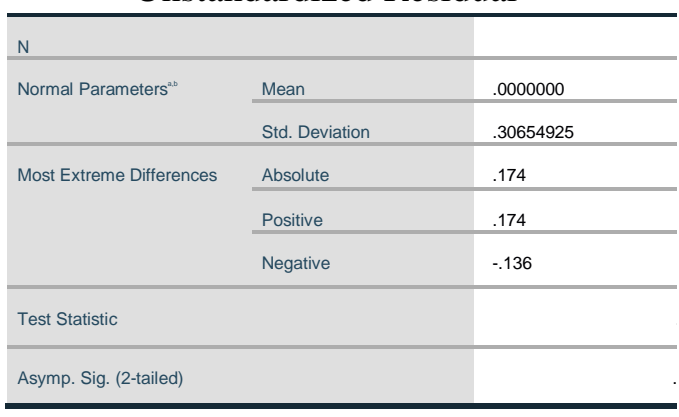

b. Uji Multikolinieritas

Perusahaan Sub Sektor Industri Kimia 
JRNAL IMMAH
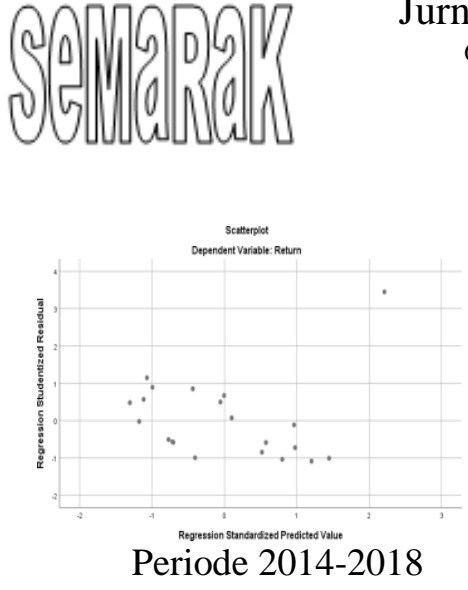

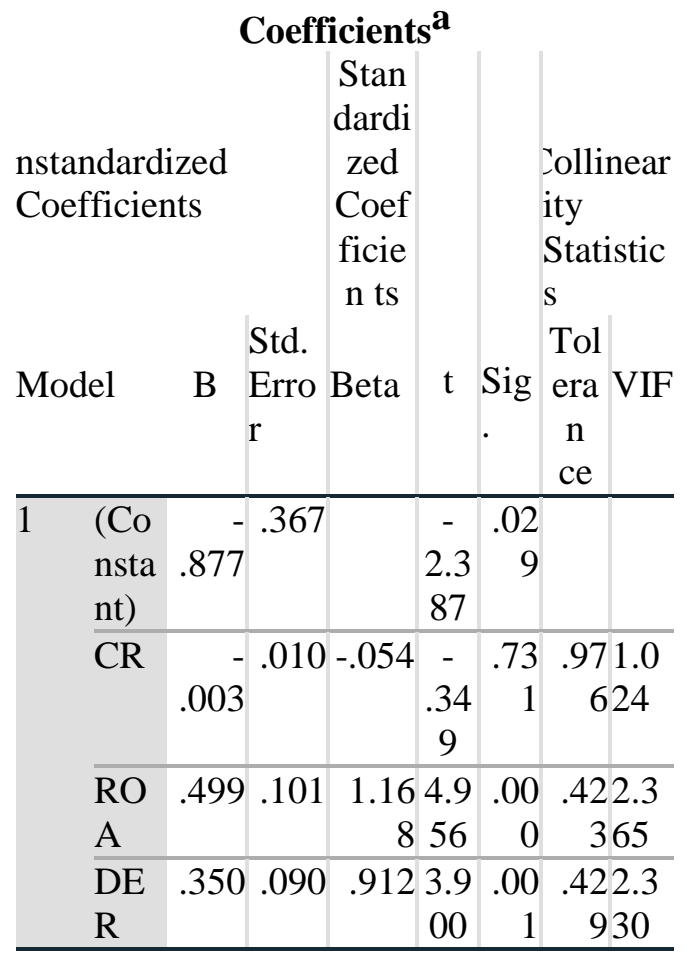

a. Dependent Variable: Return

c. Uji Autokorelasi

Hasil Uji Durbin-Watson

Perusahaan Sub Sektor Industri Kimia

Periode 2014-2018

\section{Model Summary ${ }^{b}$}

djusted Std.

$\mathrm{R} \quad$ Error of

Mo $R \quad R$ Square the Durbindel Squar Estimat Watson

\begin{tabular}{cc|c|c} 
& $\mathrm{e}$ & $\mathrm{e}$ & \\
\hline 1 & $.775^{\mathrm{a}} .601$ & .530 .33250 & 1.188 \\
\hline
\end{tabular}

a. Predictors: (Constant), DER, CR,ROA

b. Dependent Variable:Return

d. Uji Heterosekdastisitas
Hasil Uji Heterosekdastisitas Perusahaan Sub Sektor Industri Kimia Periode 20142018

B. 4Uji Hipotesis

a. Uji Regresi Linier Berganda

Uji Regresi Linier Berganda

Perusahaan Sub Sektor Indutri Kimia

Periode 2014-2018

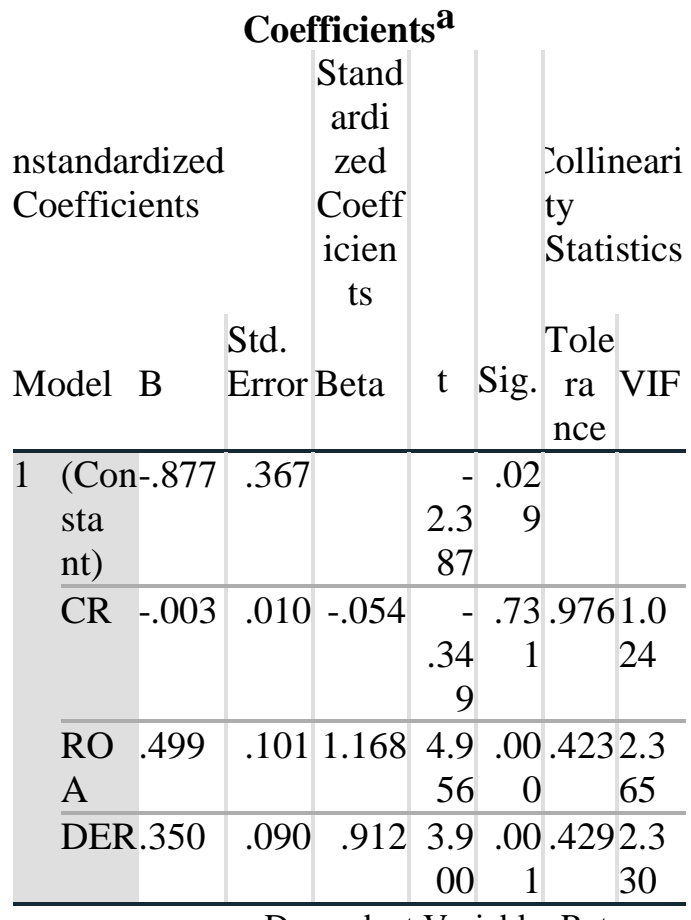

a. Dependent Variable: Return

Data yang digunakan dalam uji regresi linier berganda ini adalah data yang telah di square root dan dihilangkan data outliernya. Berdasarkan perhitungan regresi linier berganda yang ditunjukan tabel 4.9, maka persamaan regresi linier berganda sebagai berikut :

$\mathrm{Y}=-0.877+-0.003 \mathrm{CR}+0.499 \mathrm{ROA}+$ $0.350 \mathrm{DER}$

Dari persamaan regresi linier berganda dapat dijelaskan sebagai berikut:

a. Konstanta sebesar -0.877 , menyatakan bahwa apabila semua variabel indipenden tetap atausama dengan nol, maka besarnya tingkatreturn saham sebesar -0.877 satuan. 
JRNAL ПMМAH

Samidaldad

b. Variabel Current Ratio (X1) diperoleh nilai koefisien sebesar -0.003 yang menyatakan bahwa apabila pada variabel current ratio naik sebesar 1 satuan, maka return saham perusahaan sub sektor industri kimia akan naik 0.003 satuan dengan asumsi bahwa variabel independen dalam kondisi konstan.

c. Variabel Return On Assets (X2) diperoleh nilai koefisien sebesar 0.499 yang menyatakan bahwa apabila pada variabel return on assets naik sebesar 1 satuan, maka return saham perusahaan sub sektor industri kimia akan meningkat 0.499 satuan dengan asumsi bahwa variabel

d. independen dalam kondisi konstan.

e. Variabel Debt to Equity (X3) diperoleh nilai koefisien sebesar 0.350 yang menunjukkan bahwa apabila pada variabel debt to equity meningkat sebesar 1 satuan, maka return sahamperusahaan sub sektor Indutri kimia akan meningkat 0.350 satuan dengan asumsi bahwa variabel independen dalam kondisi konstan.

b. Uji t (parsial)

Perusahaan Sub Sektor Industri Kimia Periode 2014-2018

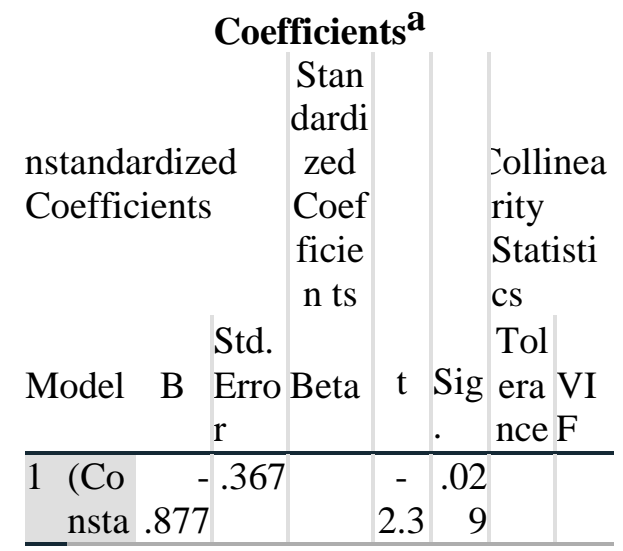

\begin{tabular}{|c|c|c|c|c|c|}
\hline nt) & & & 87 & & \\
\hline \multirow{2}{*}{ CR } & & \multicolumn{2}{|c|}{$.010-.054$} & .73 & .971 .0 \\
\hline & .003 & & $\begin{array}{r}34 \\
9\end{array}$ & 1 & 624 \\
\hline $\mathrm{RO}$ & .499 & .101 & 1.164. & .00 & .422 .3 \\
\hline A & & & 856 & 0 & 365 \\
\hline$\overline{\mathrm{DE}}$ & .350 & .090 & .9123 .9 & .00 & .422 .3 \\
\hline $\mathrm{R}$ & & & 00 & 1 & 930 \\
\hline
\end{tabular}

a. Dependent Variable: Return

Berdasarkan tabel di atas hasil uji t adalah:

1. Current ratio terhadap return saham

Data yang dipakai dalam uji $t$ (parsial) ini adalah data yang telah di square root dan dihilangkan data outlier-nya. Berdasarkan uji t (parsial) pada tabel 4.10 dapat diketahui $t$ hitung sebesar -0.349 dengan nilai signifikansi 0.731 dan t tabel 2.110 karena $-0.349<$ dari 2.110 dan nilai signifikansi $0.731>$ dari 0.05 maka $\mathrm{H}_{0}$ diterima. Artinya dapat disimpulkan bahwa Current Ratio secara parsial tidak berpengaruh signifikan terhadap return saham.

2.Return On Assets terhadap return saham

Data yang digunakan dalam uji $\mathrm{t}$ (parsial) ini adalah data yang telah di square root dan dihilangkan data outlier-nya. Berdasarkan uji t (parsial) pada tabel 4.10 dapat diketahui $t$ hitung sebesar 4.956 dengan nilai signifikansi 0.000 dan t tabel 2.110 karena $4.956>$ dari 2.110 dan nilai

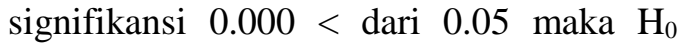
ditolak. Artinya dapat disimpulkan bahwa Return On Assets secara parsial berpengaruh signifikan terhadap return saham.

3.Debt to Equity terhadap return saham

Data yang digunakan dalam uji $\mathrm{t}$ (parsial) ini adalah data yang telah di square root dan dihilangkan data outlier-nya. Berdasarkan uji t (parsial) pada tabel 4.10 dapat diketahui $\mathrm{t}$ hitung sebesar 3.900 dengan nilai signifikansi 0.001 dan t tabel 2.110 karena $3.900>$ dari 2.110 dan nilai signifikansi $0.001<$ dari 0.05 maka $\mathrm{H}_{0}$ ditolak. Artinya dapat disimpulkan bahwa Debt to Equity secara parsial berpengaruh signifikan terhadap return saham. 
JRNAL ПMПAH

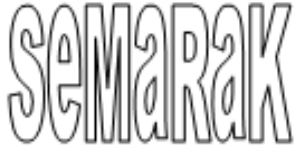

P-ISSN 2615-6849, E-ISSN 2622-3686

Jurnal Semarak,Vol.4,No.1,Februari 2021, Hal (70-79)

@ Prodi Manajemen Fakultas Ekonomi Universitas Pamulang c. Uji F

Perusahaan Sub Sektor Kimia Periode 2014-2018

\begin{tabular}{|c|c|c|c|c|c|}
\hline & & OV & & & \\
\hline & $\begin{array}{l}\text { Sum } \\
\text { of }\end{array}$ & & $\begin{array}{l}\text { Mean } \\
\text { Square }\end{array}$ & & \\
\hline $\begin{array}{l}\text { Mo } \\
\text { del }\end{array}$ & $\begin{array}{l}\text { Square } \\
\mathrm{S}\end{array}$ & $\mathrm{df}$ & & $\mathrm{F}$ & Sig. \\
\hline $\begin{array}{l}1 \text { Regre } \\
\text { ssion }\end{array}$ & 2.828 & 3 & .943 & $\begin{array}{l}38.52 \\
7\end{array}$ & $\begin{array}{l}.001 \\
b\end{array}$ \\
\hline $\begin{array}{l}\text { Resid } \\
\text { ual }\end{array}$ & 1.879 & 17 & .111 & & \\
\hline Total & 4.708 & 20 & & & \\
\hline
\end{tabular}

a. Dependent Variable:Return

b. Predictors: (Constant), DER, CR,ROA

Data yang digunakan dalam uji $\mathrm{F}$ (simultan) ini adalah data yang telah disquareroo tdan dihilangkan dataoutliernya .Berdasarkan table 4.11 diketahui nilai $\mathrm{F}$ hitungs ebesar 8.527 dengan nilai signifikansi 0.001 . Nilai $F$ tabel 3.160 karena $\mathrm{F}$ hitung $8.527>$ dari $\mathrm{F}$ tabel 3.160 dan tingkat signifikansi $0.001<$ dari 0.05 maka dapat disimpulkan bahwa Current Ratio, Return On Assets dan Debt to Equity secara simultan berpengaruh terhadap return saham di perusahaan sub sektor industri kimia.

d. $\quad$ ji Koefisien Determinasi $\left(\mathrm{R}^{2}\right)$

Uji Koefisien Determinasi $\left(\mathrm{R}^{2}\right)$

Perusahaan Sub Sektor Industri Kimia Periode 2014-2018

\section{Model Summaryb \\ djusted Std. \\ $\mathrm{R} \quad$ Error}

Mo $R \quad R \quad$ Square of the Durbin-

del Squa Estimat Watson

\begin{tabular}{ll|l|l|l} 
& \multicolumn{2}{c|}{$\mathrm{re}$} & $\mathrm{e}$ & \\
\hline 1 & .775 & .601 & .530 .33250 & 1.188 \\
& & &
\end{tabular}

i. Predictors: (Constant), DER, CR,ROA

ii. Dependent Variable:Return

Dari hasil perhitungan diperoleh hasil besarnya pengaruh variabel independen terhadap variabel dependen yang dapat diterangkan oleh model persamaan ini adalah sebesar 53,0\%. Hal ini menunjukkan bahwa besar pengaruh variabel Current Ratio, Return On Assets dan Debt to Equity terhadap return saham adalah sebesar 53,0 $\%$ dan sisanya dipengaruhi oleh faktorfaktor lain yang tidak dimasukan dalam model regresi, seperti faktor makro perusahaan, faktor ekonomi negara, dan faktor perusahaan secara umum.

\section{PENUTUP}

\section{A. Kesimpulan}

1. Pengaruh Current Ratio secara parsial terhadap return saham 6 (enam) perusahaan sub sektor industri kimia yang terdaftar di Bursa Efek Indonesia periode 20142018 secara parsial tidak berpengaruh signifikan terhadap return saham.

2. Pengaruh Return On Assets secara parsial terhadap return saham 6 (enam) perusahaan sub sektor industri kimia yang terdaftar di Bursa Efek Indonesia periode 20142018 secara parsial berpengaruh signifikan terhadap return saham.

3. Pengaruh Debt to Equity Ratio secara parsial terhadap return saham 6 (enam) perusahaan sub sektor industri kimia yang terdaftar di Bursa Efek Indonesia periode 2014-2018 secara parsial berpengaruh signifikan terhadap return saham.

4. Pengaruh Current Ratio, Return On Assets dan Debt to Equity secara simultan terhadap return saham 6 (enam) perusahaan sub sektor industri kimia yang terdaftar di Bursa Efek Indonesia periode 2014 - 2018 berpengaruh signifikan terhadap return saham .

\section{B. Saran}

1. Bagi pemakai laporan keuangan yang akan mengambil suatu keputusan investasi hendaknya 
JRNAL ПMМAH

Sammadid

tidak mengandalkan data mengenai CR, DER dan ROA saja, tetapi perlu juga memperhatikan faktorfaktor lain dan rasio-rasio lain dalam hubungannya dengan return saham seperti ukuran perusahaan, faktor ekonomi, rasio aktiva, rasio profitabilitas, rasio solvabilitas, dan likuiditaslainnya.

2. Bagi perusahaan sub sektor kimia diharapkan lebih memperhatikan kemampuan perusahaan dalam meningkatkan return saham dengan cara mengefektifkan dan mengefisiensikan penggunaan biaya sehingga meningkatkan laba, me-manage utang, mengatur penggunaan dalam hal ekspansi, dan mempertambah modal kerja yang baik dan efisien sehingga nilai perusahaan bisa maksimal.

3. Bagi peneliti selanjutnya untuk memperbanyak variabel atau menggunakan variabel lain, selain itu memperbanyak sampel penelitian agar penelitian yang selanjutnya menjadi lebih tepat dan akurat

\section{DAFTAR PUSTAKA}

Fahmi, Irham. 2013. Analisis Laporan Keuangan. Bandung: Alfabeta.

Ghozali, Imam. 2011. Aplikasi Analisis Multivariate dengan Program SPSS19.00. Semarang: Badan Penerbit Universitas Dipenogoro.

Gumanti, Ary Tatang. 2011. Manajemen Investasi-Konsep, Teori dan Aplikasi, Mitra Wacana Media, Jakarta.

Hamid, Abdul. 2012. Panduan Penulisan Skripsi. Jakarta: FEB UIN.
Hartono, Jogiyanto. 2014. Metode Penelitian Bisnis (Edisi ke-6). Yogyakarta: Universitas Gadjah Mada.

Jatmiko, Dadang Prasetyo. 2017. Pengantar Manajemen Keuangan. Yogyakarta: Diandra Kreatif.

Kasmir. 2015. Analisis Laporan keuangan. Jakarta: Rajawali Pers.

Nugroho, Agung. 2010. Strategi Jitu Memilih Metode Statistik Dengan SPSS. Yogyakarta: Andi Offset.

Sugiyono. 2011. Metode Penelitian Kuantitatif, Kualitatif dan R\&D. Bandung: Alfabeta.

Sunariyah. 2011. Pengantar Pengetahuan Pasar Modal (Edisi ke-6). Yogyakarta: UPP STIM YKPN.

Tandelilin, Eduardus. 2017. Analisis Investasi dan Manajemen Portofolio (Edisi Pertama). Yogyakarta: BPFEYogyakarta.

www.idx.co.id

www.sahamok.com

Jurnal

Prasetya, I Putu Eva, dkk. 2014. Pengaruh Current Ratio, Debt to Equity Ratio dan Return On Assets terhadap Return Saham pada perusahaan Transportasi yang terdaftar di Bursa Efek Indonesia. Universitas Pendidikan Ganesha. Jurnal Ilmiah Mahasiswa Akuntansi Undiksha. Volume 2, No. 1, 2014.

Anita Erari, 2014 yang berjudul Analisis Pengaruh Current Ratio, Debt to Equity Ratio, dan Return On Asset Terhadap Return Saham Pada Perusahaan Pertambangan di Bursa Efek Indonesia. Universitas 
JRNAL ПMПAH

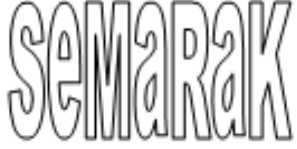

P-ISSN 2615-6849, E-ISSN 2622-3686

Jurnal Semarak,Vol.4,No.1,Februari 2021, Hal (70-79)

@ Prodi Manajemen Fakultas Ekonomi Universitas Pamulang

Cendrawasih. Jurnal Manajemen

Bisnis. Vol.5 No.2, September 2014.

Nugroho, H., \& Krisnaldy, K. (2019).

PENGARUH INFLASI, GROSS

DOMESTIC PRODUCT, BIAYA

OPERASIONAL DAN PENDAPATAN

OPERASIONAL TERHADAP

PROFITABILITAS PADA

PERUSAHAAN PERBANKAN

SYARIAH DI INDONESIA PERIODE

2012-2015. Jurnal Semarak, 2(3), 108-

125.

Purnomo, S., \& Pasaribu, V. L. D. (2019).

Pergerakan Harga Saham Pt Adaro Energy Tbk (Adro) Pada Pengumuman Dividen Interim

Tahun Buku 2018. Jurnal Ekonomi

Efektif, 2(1).

Tumanggor, M., Satria, R., Jamaludin, D. N. R. P., \& Oktrima, B. (2020). Effect of Costs and Operational Income (Bopo), Capital Adequacy Ratio (Car), and Net Performing Loan (Npl) For Return on Asset (Roa)(Empirical Study of Go Public Banking 2011-2017). Solid State Technology, 63(6), 1390-1396.

Zamzami, K.K. 2015 yang berjudul Pengaruh Retun On Asset (ROA), Debt to Equity Ratio (DER), Current Ratio (CR), Dan Total Assets Turnover (TATO) Terhadap Return Saham pada Perusahaan yang Masuk dalam Kategori Indeks LQ-45 di Bursa Efek Indonesia. Universitas Djuanda. Jurnal AKUNIDA. Volume 1 Nomor 1, Juni 2015. 